\title{
内斜視から外斜視へ自然移行する症例
}

\author{
村松 春美・岩野えみ子・山本 裕子 \\ (自治医大)
}

\section{Esotropic patients convert naturally to exotropic without surgical correction.}

\author{
Harumi Muramatsu, Emiko Iwano, Hiroko Yamamoto \\ Jichi Medical School
}

1974年 4 月から 1988 年 3 月の 14 年間に当科弱視斜視外来を受診した初診年齢10歳以下で， 1 年以上経過観 察できている，斜視の手術の既往のない内斜視患者を検討した。

その総数は699例で，そのうち手術をせず自然に外斜視に移行した症例は32例であった. 自然に外斜視に移 行した割合は全体の $4.6 \%$ であった。

自然に外斜視に移行した群とその他の群との間に有意差のあったものは，1) 初診時に固視交代不良，2) $2 \mathrm{D}$ 以上の不同視，3）両眼 $6 \mathrm{D}$ 以上の遠視，4）眼外異常を合併するものであり，これら 4 つの要因のう ち 1 つ以上持った症例は外斜視移行群では全例 $100 \%$ であり，その他の群では 232 例 $34.8 \%$ ，両者に有意差 を認めた。

これらの要因を持つ内斜視の治療にあたつて注意が必要と考えられた。

It has been reported that some esotropic patients convert naturally to exotropic without any surgical correction. The etiology for this phenomenon, however, still remains unknown. In order to study the incidence and mechanisms for the naturally occured consecutive exotropia, we carried out clinical analyses of the esotropic patients.

The subjects studied are 699 esotropic patients who have been followed up with full correction of refractive errors but without any surgical treatment. The patients were classified into two groups, i. e., patients who remained esotropia or orthophoria and ones who converted naturally to exotropia during the follow-up period. We have studied the several clinical factors retrospectively. The incidence of the factors were calculated for each group and compared it between the two groups.

We have found that 32 of 699 patients $(4.6 \%)$ changed to exotropia without any surgical intervention during the observation period. We have also found that the incidence of 1) fixation anomaly of one eye for the first visit, 2) anisometropia over $2.0 \mathrm{D}, 3$ ) hyperopia over $6.0 \mathrm{D}$ of both eyes and 4) systemic complications such as microcephalus, cerebral palsy, epilepsy is significantly higher in the group of consecutive exotropic patients than another group.

We can conclude from these results that we must take care of the operaton of the esotropic child with fixation anomaly, anisometropia, hyperopia over $6.0 \mathrm{D}$ of both eyes and abnormalities of central

連絡先 栃木県河内郡南河内町薬師時3311-1

nervous system.

自治医大女子寮 $\mathrm{E}-301$

TEL 0285-44-2111（内線4591）

Key words: Esotropic patients convert to exotropia,

Anisometropia,

Fixation anomaly,

Hyperopia over $6.0 \mathrm{D}$,

Abnormalities of central nervous system.

\section{I .はじめに}

内斜視の症例中に手術をせずに自然に，時間 経過とともに外斜視に移行していく症例がある ことは，これまでにも報告されている1). しか し，どのような要因があるときに外斜視に移行

しやすいかという点については，まだ明らかに 
されているとはいえない.

また，手術を必要とした内斜視患者が，術後 に外斜視となる症例の数が予想より多いことは, 第29回日本視能矯正学会で, 当科からも報告し

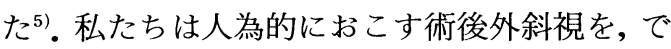
きる限り少なくしたいと考えている，そのため にも自熱経過で外斜視に移行する症例の特徵を 知ることは有意義なことと考える.

今回ここでは, 自治医大眼科において経過観 察してきた症例のなかで, 自然に外斜視に移行 した症例について検討し，その臨床的特徵に若 干の知見を得たので報告したい。

\section{II. 症例}

検討した症例は，1974年 4 月から1988年 3 月 の間に当科弱視斜視外来を受診した内斜視患者 699例である.これは, 初診年噛が10歳以下で 1 年以上経過観察できている，斜視の手術の既往 の無い内斜視症例から, 外直筋麻痺, 開散麻痺, 隔日型内斜視, Duane 症候群の患者を除いたも のである.

\section{III. 結 果}

対象となった内斜視症例のうち, 経過観察中 自然に外斜視に移行したものを $\mathrm{EX}$ 群とし，そ れ以外の正位を得たものと内斜視のまま留まっ たものを $\mathrm{E}$ 群とした。

\section{1) 頻度}

$\mathrm{E}$ 群は667例, EX 群は32例であり, 全内斜視 699例のうち $\mathrm{E}$ 群は95.4\%, EX 群は4.6\%で あった（表 1 ).

\section{2 ) EX 群の臨床的特徵}

対象となった症例の臨床的特徴について, retrospective に検討した結果を表 2 に示す。

\section{a) 調 節 要 因}

屈折矯正で $2 \mathrm{D}$ 以上の遠視の眼鏡を装用し正 位，あるいは斜視角が減少する症例，すなわち 調節要因を持つ症例は全体699例中では528例 $75.5 \%$ でった。その調節要因を持つ症例が EX 群は32例中 28 例で $87.5 \%$ ，E群は667例中 500 例で $74.6 \%$ であった。
表 1 外斜視自然移行例

$$
\text { 例数 }
$$

EX群 $32 \quad(4 \cdot 6)$

E 群 $667 \quad(95 \cdot 4)$

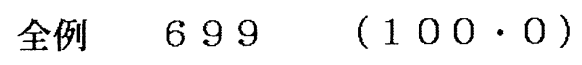

表 2 検査項目別各群の結果

\begin{tabular}{|l|ccc|ccc|c|}
\hline & \multicolumn{3}{|c|}{ EX群 } & \multicolumn{3}{|c|}{ E群 } & \\
検查項目 & $\mathrm{n}$ & 例数 & $\%$ & $\mathrm{n}$ & 例数 & $\%$ & 有意差 \\
\hline$+2 \mathrm{D}$ 以上 & 32 & 28 & $87 \cdot 5$ & 667 & 500 & $74 \cdot 6$ & - \\
+60 以上 & $\prime \prime$ & 12 & $37 \cdot 5$ & $\prime \prime$ & 101 & $15 \cdot 1$ & + \\
固視交代不良 & $\prime \prime$ & 14 & $43 \cdot 7$ & $\prime \prime$ & 103 & $15 \cdot 4$ & + \\
2 以以上の不同視 & $\prime \prime$ & 5 & $15 \cdot 6$ & $\prime \prime$ & 36 & $5 \cdot 4$ & + \\
眼外以上合併 & $\prime \prime$ & 10 & $31 \cdot 3$ & $\prime \prime$ & 75 & $11 \cdot 2$ & + \\
D.V.D (+) & 30 & 12 & $40 \cdot 0$ & 612 & 181 & $29 \cdot 6$ & - \\
S.P (+) & $\prime \prime$ & 28 & $93 \cdot 3$ & 572 & 486 & $85 \cdot 0$ & - \\
\hline
\end{tabular}

なお，屈折度はすべて，全例において調節麻 痺剤点眼後のもので, 乱視のある場合は等価球 面值で表わした。

\section{b) 高度遠視}

高度遠視の $6 \mathrm{D}$ 以上を両眼に持つものが $\mathrm{E}$ 群 では101例 (15.1\%)，EX 群では12例 (37.5\%) であった。

\section{c) 固 視}

初診時の固視の状態と眼位の変化について検 討するため, 中心固視良好な群と固視に問題の ある群にわけた。乳児期にはvisuscopeによる 固視検査ができないため, 角膜反射とカバーテ ストによる検査で6)，固視交代不能のものを固 視に問題ある群とし, 年長児では, 矯正視力が 0.2 以下で visuscope でも中心固視不良のもの を，固視に問題ある群とした。

その結果，初診時に固視に問題のあった症例 


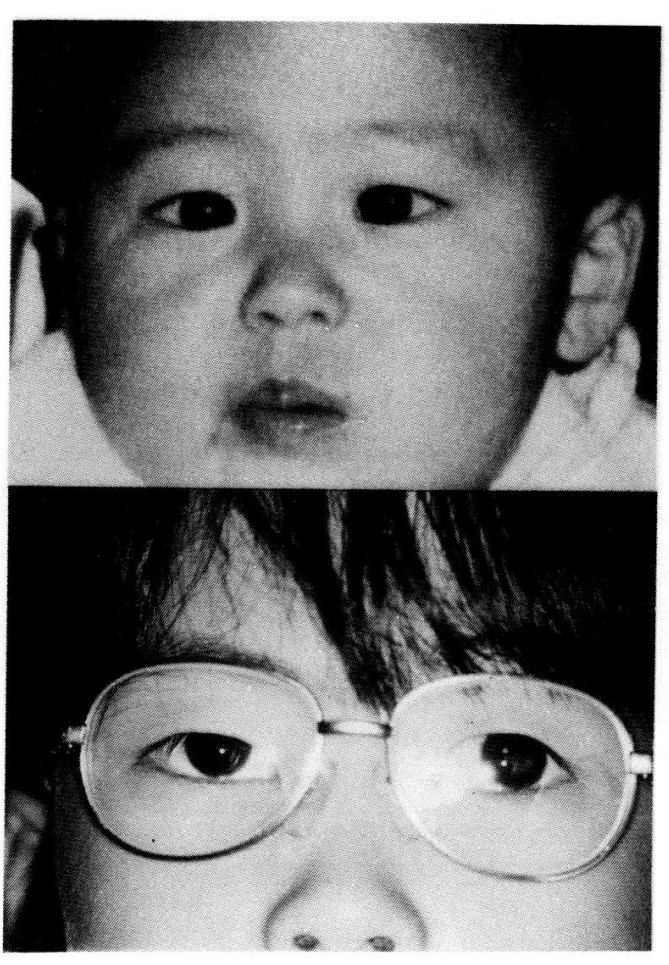

図 1

は, E群では103例 (15.4\%), EX 群では14例 (43.7\%) であった。

\section{d) 不 同 視}

両眼の屈折度の差の平均值は $\mathrm{E}$ 群 $0.56 \mathrm{D} \pm$ 1.02 , E X群 $1,12 \mathrm{D} \pm 1.30$ であり, 両眼の不同 視の程度が $2 \mathrm{D}$ 以上あるものは, $\mathrm{E}$ 群36例 (5.4\%), EX 群 5 例 (15.6\%) であった。

\section{e ) 眼外異 常}

精神, 身体の発達遅滞のもの, 出生時の異常 のあるもの (未熟児, 低体重児), 脳性麻痺, 䯪 痭，小頭症などをまとめて眼外異常とすると， それらが合併しているものは，E群では75例

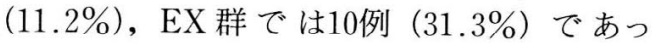
た.

\section{f）乥の 他}

初診年齢の平均は, $\mathrm{E}$ 群が 4 歳 1 力月 \pm 3 歳 2 力月, $\mathrm{EX}$ 群が 3 歳 0 力月土 2 歳 1 力月で あった。

$\mathrm{EX}$ 群についてのみ調査し得た結果として, 内斜視発症年齢は, 平均 1 歳 5 力月 1 歳 3 力 月 ( 1 力月から 6 歳), 切斜視になり始めた年齢
は, 平均 6 歳 4 力月 \pm 2 歳 7 力月（1歳から 12 歳)であった。

また大型弱視鏡において他覚的斜視角が検査 可能であった症例は E 群612例, EX 群30例で あった。そのうち交代性上斜位 (DVD) を伴っ たものは，E群は181例 (29.6\%) EX 群は12例 (40.0\%) であった。

両眼視機能については, 大型弱視鏡において 自覚的斜視角が検査可能であった症例, $\mathrm{E}$ 群 572 例, EX 群30例について検討した. 同時視のあっ たものは, E群は486例(85.0\%), EX 群は28例 (93.3\%) であった.

\section{IV. 考察}

内斜視には，将来自然に外斜視に移行して行 くものさえあるという事実を認識しないまま， 経過を見ず手術することには問題がある.

著者らは, 比較的多数の症例を長期にわたつ て観察することができたので，全内斜視のうち で自然に外斜視へ移行するものの割合を検討し てみた。

自然に外斜視に移行した症例は32例であり， 全内斜視の $4.6 \%$ ものが手術をせず自然に外 斜視になったという結果が得られた。

その外斜視に自然移行した 32 例を，その他の 群と比較検討した。

\section{1) 固 視}

乳児期の患者も含めて, 初䛦時に固視交代に 問題のあったものは, E群で15.4\%, EX 群では $43.7 \%$ あ゙り, 両者には統計的に有意差が認め られた。

中心固視不良の弱視においては1987年臼井・ 久保田 (らはその要因として低視力と中心固視 機能そのものの異常をあげ,この異常の改善を 弱視治療のねらいとしている. しかしその第一 選択の治療法としての遮蔽にも問題があり, 予 後について 1973 年に山本 ${ }^{8)}$ が, 視力は回復して も完全な両眼視機能獲得は困難であると報告し ている.

今回の症例の14例についても弱視を疑われた 初診時より，ほとんどは健眼遮蔽，あるいはま れに患眼遮蔽と中心固視獲得訓練の併用が実行 
され,矯正視力は 1 例をのぞいた全 13 例が 1.0 か ら1.2を得た。そして眼位も一時は正位を得たに もかかわらず，次第に外斜視に移行する率が高 い，つまり正常な眼位を保つことができないと いうことは, 斜視における固視の重要性, 特異 性を表わすものと考えられる。

自然外斜視における弱視との関係は Moore, Beneishire がそれぞれ健眼と 3line，2line 以上 の差の有るものを検討し, 重要な要因ではない としている。この結果は, 初診時の固視の状態 を問題としている著者らと直接比較はできない と考える. 今回の結果が得られたことから，外 斜化の要因として，これまでの報告のように弱 視，とくに固視不安定の要因を否定することは できない.

\section{2 ) 不 同 視}

$2 \mathrm{D}$ 以上の不同視を持つものは, $\mathrm{E}$ 群 $5.4 \%$, EX 群は15.6\%であり，統計的に有意差が認め られた。全例についての左右眼の差についても， $\mathrm{E}$ 群は平均 $0.56 \mathrm{D} \pm 1.02$ に対し $\mathrm{EX}$ 群において は1.12D \pm 1.30 と大きくなっている.

一般に左右眼に $2 \mathrm{D}$ 以上の差のある不同視は 屈折異常全体の $10 \%$ 以下と報告され, また屈折 異常度が大なるほど, 不同視の程度が大なるほ ど視機能障害が起こり易いとされている 回の結果からも, 不同視は眼位安定の阻害要因 の 1 つと考えられた。

\section{3 ) 両眼 6 D以上の遠視}

高度遠視の $6 \mathrm{D}$ 以上を両眼に持つものは， $\mathrm{E}$ 群では $15.1 \%, \mathrm{EX}$ 群では37.5\%にあたり, 統計 的に有意差が認められた。

この点に関して更に，今までの報告 ${ }^{1) \sim 4)}$ で特 徵とされている $4.5 \mathrm{D}$ 以上を持つものについて も検討した。 E群では217例 $32.5 \%$ ，EX 群では 15 例 $46.9 \%$ であり, $4.5 \mathrm{D}$ 以上の遠視でみると両 者に統計的有意差は得られなかった。

$6 \mathrm{D}$ の遠視は, 丸尾 ${ }^{10)}$ がいう近視の多い日本 人の正常範囲（+4 Dから-6 D ）を逸脱して おり, 病的屈折異常に分けられ, 丸尾は約対遠 視として弱視に陷る要因としている。

大きな屈折異常の影響は, 視力のみならず,
両眼視の発達に及ぶものと考えられ，眼位の安 定化の阻害要因になり得ると推測される.

\section{4 ) 眼外異常所見}

身体あるいは精神的な成長発達に問題のある 症例 (未熟児, 低体重児 ${ }^{11)}$ を含む) や出産時の異 常, 癲癇, 小頭症をもった症例が EX 群で $31.3 \%$ ，E群では $11.2 \%$ であって，これらにも 統計的有意差が認められた。

乳幼児の視覚発達の研究は古くより行なわれ ている。植村ら ${ }^{12)}$ の報告では新生児はおよそ 0.03 から 0.05 という視力であり, 生後より 6 力 月までに, OKN, PL, VEP の 3 つの方法によっ て，0.1から0.3前後に達するとしている．従っ て生直後の発達がその後の成長に大きく影響す ることが考えられ，生来発達の異常を持った子 供の視機能, 及び眼位の安定に影響を与えるも のと推定される。

\section{5）高 他}

両眼視機能については，これまでの報告 ${ }^{1)}$ 同様，正常対応が多く，今回同時視において検 討した結果は E 群 $85.0 \%$ ，EX 群 $93.3 \%$ でその 間に差は認められなかった。

また交代性上斜位の合併が $\mathrm{E}$ 群 $29.6 \%, \mathrm{EX}$ 群 $40.0 \%$ であった．眼位の動摇が特徵である交 代性上斜位は，外斜視への移行に意味をもって いることが推定されるが，今回は両者に統計的 有意差を得られなかった。

年齢については, 内斜視発症年齢が 2 歳前後, 外斜視発症年齢は幼若な年齢ではなく学童期全 体であるとするこれまでの報告とほぼ一致して いた。

またこれまで，内斜視の自然外斜視移行は N P.C. (near point of convergence) の減弱や潜 在的に外斜視で有るものの戻りであることを指 摘するものもある。しかし外斜視発生後も近見 眼位は過剰に輻輳しているものがあること，眼 鏡装用後まもなく外斜視が現われたのではなく， 初診年齢が 3 歳 0 力月で外斜視発症年齢が 6 歳 4 力月と, 眼鏡装用開始から平均 3 年の経過期 間があり，一度は正位を得ていたのに次第に外 斜化していることは，これらの説に合致しない。 
最後に, 今回 $\mathrm{EX}$ 群と $\mathrm{E}$ 群の間に有意差を認 めた 4 つの臨床的特徵は, 固視交代不良, 高度 遠視，2D以上の不同視，眼外異常の合併であ り,これらの要因を一つ以上持つ症例が, $\mathrm{E}$ 群 が232例 $34.8 \%$ でるのに対し, EX 群は32例全 例， $100 \%$ に認められた. 即ち，自然に外斜視に 移行した全例が，これらの臨床的特徴を 1 つ以 上もっており，その他の症例にみられるよりも 有意に高頻度であった。

\section{V. 結 論}

1 年以上経過観察できた，10歳以下の内斜視 症例699例のうち,手術をせず自然に外斜視に移 行した症例は 32 例， $4.6 \%$ であった。

外斜視に移行した群とその他の群との間に有 意差があったものは，次の点であった。

1. 初診時に固視交代不良。

2. 両眼に 6 D 以上の遠視.

3. $2 \mathrm{D}$ 以上の不同視.

4. 眼外異常の合併.

そして外斜視自然移行群では，全例にこれら 4 つの要因のうち 1 つ以上が認められた。

（終りに，ご指導頂いた清水昊幸教授をはじめ 教室の諸先生方，ならびにご協力頂いた O. R. T.の皆様に深く感謝致します.)

\section{文献}

1) Moore, S.: The natural course of esotropia,
Am. Orthopt. J., 21 : 80-83, 1971.

2) Burian, H. M. : Hypermetropia and esotropia, Pediatric. Opthalmol. J., 9 : 135-143, 1972.

3) Beneish, R. Williams, F. et al. : Consecuitive exotropia after correction of hyperopia, Can. J. Ophthalmol., 16:16-18, 1981.

4）根本加代子：二次的外斜視に移行した調節性内斜 視，日本視能訓練士協会誌，12：70-74，1976.

5）色川幸子・筑比地清美・山本裕子：内斜視術後の 外斜視について, 日本視能訓練士協会誌 17 ： 123-127, 1989 .

6）山本裕子：固視検查，斜視 - 弱視の診断検查法, 8-11, 医学書院, 東京, 1986 .

7）帠井千恵・久保田伸枝：内斜視に伴った固視不良 弱の成因, 眼臨, 81：115-120，1987.

8）山本裕子：視能訓練の適応について, 眼臨, 67 : 1134-1136, 1973

9) 保坂明郎：不同視の屈折矯正と不等像視，眼科 Mook, 18:157-166, 1982.

10）丸尾敏夫：小児の屈折異常, 眼科. 28 : 1459-1463, 1986.

11）奥山和男・飯島健志・他：新生児未熟児の扱い方， 東京医学社，436-454，1988.

12）植村添夫：乳幼児の視覚発達に抢ける最近の研究 と動向, 眼科, 28 :1451-1458, 1988.

質問

（帝京大）岩重 博康

今回の症例で眼外異常は何\%あったか. XTに移行 する年齢が平均 6 歳 4 カ月だがそれについてどう思う か.

\section{答弁}

$\mathrm{EX}$ 群は 10 例, $31 \%$ にあった。文献的に XT に移行する のは 6 歳〜学童期にわたるといわれているが，眼の発 育も関与し, 両眼視機能が悪いと眼位に動摇を来し, XTになるようだが理由は不明である。 